\title{
Berács József*
}

\section{Tudásexport a felsőoktatásban: egy hierarchikus megközelítés}

A tudásipar növekedésével párhuzamosan egyre nő a felsőoktatás szerepe a gazdasági növekedésben. Egyes becslések szerint a diákmobilitásból származó exportbevétel világméretekben meghaladja a 40 milliárd dollárt. A tanulmányban e jelenségcsoport két oldalát vizsgáljuk. Elöször leszögezzük, hogy a felsöoktatás mint iparág sokkal összetettebb annál, minthogy csak a diákmobilitásról szóljon. Ez annak ellenére igaz, hogy az exporttevékenységnek ez a legvonzóbb és a leglátványosabb területe. Az egyetemek azonban rendelkeznek kutatási eredményekkel és más szolgáltatásokkal mint exporttevékenységekkel, amelyeket piaci alapon értékesítenek. Másodszor, az egyéni tanárok mint egyetemi munkavállalók vagy szabadúszó tudásmunkások, továbbá a tanszékek, karok, egyetemek, országok, régiók stb. egyaránt szolgálhatnak a tevékenységek statisztikai számbavételi egységeiként. Az egyetemek által ellátott összes tevékenység mérhetö különböző hierarchikus szinteken.

Journal of Economic Literature (JEL) kód: F14, M31

Kulcsszavak: felsőoktatás, export, diákmobilitás, kutatási teljesítmény, szolgáltatás

\section{Bevezetés}

A globális versenyben egy olyan kis ország, amely viszonylag több saját terméket tud exportálni (Finnország, Svédország, Svájc stb.), versenyképesebb, mint az, amelyik csak belföldre tudja értékesíteni nemzeti termékeit. Ebből az alaptételből kiindulva próbáljuk meg a tanulmányban felvázolni, hogy a felsőoktatás mint a modern gazdaság egyre meghatározóbb szegmense, miként jelenik meg az exportban. A statisztikai hivatalok általában nem tartják nyilván külön soron, hogy egy adott évben a felsőoktatási szolgáltatás milyen része került exportra. Ennek két oka van. Egyrészt, a felsőoktatási ágazat csak az elmúlt évtizedekben kezdett iparszerüvé válni. Ennek következtében más ágazatokhoz képest a felsőoktatási exportforgalom értéke piaci viszonyok között nem volt jelentős. Másrészt, a többnyire közszolgáltatási jellegü szolgáltatásra inkább jellemző, hogy a külső piacoktól elzártan müködik, nagyrészt közpénzekből. A 21. század elejére érett meg a helyzet arra, hogy már globálisan is felmerül a felsőoktatás exportképessége. Az információs évszázadba lépve markánsan kezd elválni a tudomány és az oktatás exporttermelö képessége.

\footnotetext{
* Berács József egyetemi tanár, a Budapesti Corvinus Egyetem Nemzetközi Felsőoktatás Kutató Központjának társigazgatója, e-mail:jozsef.beracs@uni-corvinus.hu.
} 
A vezető államok, mint az Egyesült Államok, Ausztrália stb. már számszerüsítik is ezeket a területeket. Így például az Egyesült Államok a külföldi felsőoktatási diákokból nemzetgazdasági szinten 14,5 milliárd dollárt realizált a 2006-2007-es tanévben (tandíj és megélhetési költség). Öt év után ismét emelkedett, 3,2 \%-kal a külföldi hallgatók száma, és elérte az 582984 föt. Szintén jelentős, hogy az első három küldő országból nagyobb volt a növekedés - India (10\%), Kína (8\%), Korea (6\%) -, ami jelzi a koncentráció növekedését is. (Forrás: www.opendoors.iienetwork.org.) A kereskedelmi minisztérium jelentése szerint ez a bevétel már az ötödik helyet foglalja el a szolgáltatási ágazatok exportrangsorában.

A legújabb statisztikák szerint Magyarországon mintegy 12 ezer külföldi diák tanul, és nyolcezer magyar diák tanul külföldön (az Oktatási Minisztérium közleménye). Míg az itt tanuló külföldi diákok száma csökkenő tendenciát mutat, vagy legalábbis megtorpanni látszik, addig egyre több magyar hallgató megy külföldre. A statisztikai források különbözösége, illetve megbízhatatlansága ellenére általános az a vélekedés, hogy a magyar felsöoktatás versenyképessége általában, de különösen az exportképessége, csökkenö trendet mutat. Kérdés, hogy a diákmobilitás mellett a tudomány, valamint az oktatást és a kutatást kiegészítő szolgáltatások területén mi a helyzet. Hogyan értelmezhető az export ez utóbbi területeken? Van-e lehetőség arra, hogy egyetlen számmal kifejezzük egy ország, egy egyetem vagy egy tanszék, illetve más entitások exportteljesítményét?

Ezek a kérdések felvethetők az egyetemek, karok, képzési programok szintjén is. A vezetö magyar orvosi egyetem, a SOTE képzésében már minden második hallgató külföldi, és az egyetemnek évente hárommilliárd forint bevétele származik a külföldi hallgatókból (Tulassay Tivadar rektor Hír Tv-nyilatkozata). Az amerikai helyzettől eltérően azonban nem ismert, hogy a nemzetgazdaságnak mekkora exportbevétele származik az egyetemi oktatásból, kutatásból és az egyéb felsőoktatási tevékenységből.

Szükség van olyan alap- és alkalmazotti kutatásokra, amelyek megbízható adatokat, információkat szolgáltatnak nem csupán a felsőoktatásban tanuló külföldi diákokról, hanem a gazdaságpolitikusokat és az egyetemek vezetőit is jobban érdeklő ágazati, intézményi exportról, exportképességről.

A probléma általános jellege miatt elöször a módszertani alapokkal foglalkozunk. A tanulmány célja, hogy a felsőoktatási export, szükebben tudásexport számbavételének lehetséges módszertani alapjait lefektesse. További tanulmányokra, elemzésekre, esettanulmányokra van szükség ahhoz, hogy meg tudjuk becsülni egy ország, egy egyetem (mint Magyarország vagy a Budapesti Corvinus Egyetem) együttes exporttevékenységét.

\section{A felsőoktatási tudásexport fő területei}

A felsőoktatási intézményeket a vállalatokhoz hasonlóan vizsgálva, felvethető a kérdés: mit tudnak exportpiacra bocsátani. A legnyilvánvalóbb válasz, hogy az oktatási tevékenységüket. Ezzel foglalkoznak a legtöbbet az intézmények a külföldi hallgatók toborzása kapcsán. Ezek a számok természetes mértékegységben (fö) és pénzösszegben (tandíjbevétel) is kifejezhetők. Az egyetem azonban kutatási tevékenységet is folytat, aminek az eredménye exportbevételt is hozhat. Ugyanakkor az intézmény egyéb tevékenységeit - kollégiumi elhelyezés, vendéglátás, munkahely-közvetítés stb. - is kiajánlhatja külföldi állampolgároknak, amivel egyfajta turisztikai szolgáltatást is nyújt. Ez a három terület az, ahol az egyetemek exporttevékenysége a számviteli előírások szerint és a megfelelő statisztikai számbavételi eljárások 
bevezetése után nyomon követhető és a szélesebb közvélemény, valamint a tulajdonos számára is hozzáférhetővé tehető.

A felsőoktatás azonban sajátos iparág abból a szempontból, hogy a munkavállalói közülük is az oktatói, kutatói - tulajdonképpen szellemi szabadfoglalkozásúak. Tudásukat egyénileg is hasznosíthatják, azaz oktatást, kutatást végezhetnek külföldi intézmények megrendelésére, miközben egy magyar oktatási intézmény állományában vannak. Ennek a tevékenységnek a bevétele nem jelenik meg az egyetem formális számviteli rendszerében, de egyes, nemzetközi hírü tudósok esetében nagyon is fontos lehet az export szempontjából. Az ország számára ez exporttevékenység, ami a globalizáció hatására egyre növekvő szerepet játszik. Ennek meghatározását becslés és megkérdezéses vizsgálat biztosíthatja.

A következőkben ezt a négy területet vizsgáljuk, mert ez az a négy terület, amelyeknek minden felsőoktatási intézmény exportmérlegében önálló soron kellene megjelenniük. Egy-egy intézmény erőssége más-más soron bontakozhat ki. Így például egy turisztikai képzéssel foglalkozó föiskola diákjai az itt elköltött pénzük nagyobb részét országjárásra, vendéglátásra, kollégiumra fordítják, és kisebb hányad kerül az oktatásra. Egy nemzetközi hírü tudományegyetemnél viszont a magas tandíj mellett megjelenhet a külföldi megrendelésre végzett laboratóriumi kísérlet. Az igazi kérdés, hogy az intézmény összevont árbevételéből mekkora rész származik külföldröl.

\section{Diákmobilitás és export}

Ezen a területen rendelkezünk a legtöbb adattal, ami a természetes egységekben való mérést jelenti. Az egyetemeknek évente beszámolót kell készíteniük, általában október 15-ei fordulónapon az intézményeikben tanuló külföldi hallgatókról, az adott tanulmányi évben végzettekről. A következő adatokat tartjuk fontosnak számba venni.

Diplomát nyújtó képzésben részt vevő külföldi hallgatók száma és az értük fizetett tandíj, költségvetési hozzájárulás. Pénzforgalmi szemléletben minden egyes hallgatóhoz hozzárendelhető az a pénzügyi forrás, ami az adott évre biztosítja a tanulmányai fedezetét. Itt legalább három hallgatói részcsoportot lehet elkülöníteni. Egyrészt azok a hallgatók, akik tandíjat fizetnek és idegen nyelvü programokban vesznek részt. Másrészt azok, akik ugyan külföldi állampolgárok, de magyar nemzetiségüek, és államközi megállapodás alapján tanulnak itt. Jóllehet az utánuk fizetett költségvetési támogatás az ország számára nem exportbevétel, de az egyetemi tudásértékesítés szempontjából tudásexportnak minősül, és célszerű külön soron megjeleníteni. Harmadrészt vannak olyan külföldi hallgatók, akik az adott országban élnek, esetleg korábbi középfokú tanulmányaikat is az adott országban végezték, de még nem szereztek állampolgárságot (például kínai hallgatók Magyarországon, vagy török hallgatók Németországban). Ök különböző programokban és tandíkonstrukcióban szerepelhetnek.

Külföldi részképzésen (study abroad) itt tanuló hallgatók, akik nem diplomáért jönnek, de piaci árat (tandíjat) fizetnek a szolgáltatásért. Elsősorban az amerikai diákok tartoznak ebbe a körbe, de a részarányuk várhatóan növekszik más, Európán kívüli országokból is.

Cserehallgatók száma. A hivatalos magyar minisztériumi (OKM) statisztikákban ezek a hallgatók nem jelennek meg, mert helyettük magyar hallgatók tanulnak külföldön. Számuk az Erasmus és más kétoldalú megállapodások alapján, különösen az Európai Unión belül, egyre növekszik. Jóllehet itt formálisan nem keletkezik az intézmény és az ország számára exportbevétel, de közgazdasági megfontolásból igen. Nevezetesen: az eltérő piaci 
árú programok bartercseréjében az alacsonyabb fejlettségü ország pozitív külső gazdasági hatást (externáliát) realizál. Autós példával szemléltetve: olyan, mint amikor egy régi szocialista Wartburgot cserélünk Volkswagenre, vagy amikor az NDK és az NSZK hivatalosan egy az egyben cserélte a márkát. Mindenki tudta, hogy az NSZK márka többet ért.

Ha tehát egy budapesti közgazdasági egyetemi diák a London School of Economicsban (LSE) cserehallgató, és az LSE hallgatója Budapesten tanul, akkor ugyan nem történik pénzügyi tranzakció, de nominálisan a magyar hallgató körülbelül négyszer nagyobb csereértékü termékhez jut, mint angol társa. (Azt feltételezve, hogy az angol képzés egy hallgatóra vetítve 10 ezer, míg egy magyar hallgatóra vetítve 2500 euróba kerül az államnak.) Minél drágább külföldi intézményekbe sikerül a hallgatókat küldeni, annál nagyobb értékhez jut az egyén és az ország is. Az ilyen módon kalkulált indirekt exportbevételt lehet alulról építkezve nominálisan meghatározni és összegezni, illetve lehet tompítottan, vásárlóeröparitáson számolni. Ez utóbbit tartjuk indokoltnak. Így például, ha Anglia esetében vásárlóerő-paritáson a magyar GDP 60 százalékon áll, akkor a 10 ezer euró helyett hatezer euróval érdemes számolni. Tehát a barterügyleten realizált exportbevétel (mert a közgazdasági egyetem képes volt egy LSE-hallgatónak megfelelő szolgáltatást nyújtani) 7500 euró helyett 3500 eurót tesz ki. Ezt célszerü az exportmérlegben megjeleníteni.

Ugyanezt a számítási metódust alkalmazva a nálunk szegényebb országokban (például Románia) diákcsere esetén az egyén és az ország is veszteséget szenved el. Ha például a romániai képzés vásárlóerő-paritáson számolt költsége 2000 euró, akkor minden hallgatói csere után 500 euró veszteség éri az intézményt, ami csökkenti az exportot. Viszont az állami „jótékonykodás” kategóriájába sorolható, miként teszi ezt Anglia és minden fejlett ország a szegényebb országokkal.

\section{Tudományos kutatás, publikációk}

A tudományos eredmények piaci értékének meghatározása elméleti és gyakorlati nehézségeket okoz. Ez az a terület, ahol a leginkább szükség van elméleti és gyakorlati kutatásokra. Az itt következő okfejtésünk az első közelítés ehhez a problémához. Alapvetően kétféle módon közelíthetünk a kérdéshez.

Először alulról építkezve minden tudományos produktumhoz hozzárendelünk egy összeget, amit a piacon adnak érte. Ha ez az összeg külföldről jött, akkor az exportkategóriába kerül. Közismert, hogy Magyarországon a tudományos kutatási alap, az OTKA éves szinten mintegy ötmilliárd forint kutatási bevételt jelent az intézményeknek. Ez hazai forrásból jön, tehát nem exporttevékenység. Ha viszont uniós alapokból jut egy bizonyos összeg Magyarországnak, akkor az már exportnak számít. Az egyetemek külföldi vállalati megbízásokra kutatásokat végezhetnek, tanulmányokat írnak, amiért pénzt kaphatnak, és ezeket szintén ezen a soron kell feltüntetni. A gyakorlatban azonban nagyon alacsony összeg jön ki ebből az eljárásból, aminek az az oka, hogy a tudományos kutatás egy sajátos jószág, amelyben a magán-és a közjószág szerep nagyon keveredik, és ez utóbbi dominál. Nevezetesen, hogy a publikációkért nem fizetnek, viszont mindenki hozzáférhet. Emiatt van szükség egy másik logikára is.

Másodszor a kutatók munkaidejéből kiindulva becslést végezhetünk arra nézve, hogy mennyi időt fordít kutatásra és kiemelten exportot eredményező kutatásra, majd ezt a munkabérrel megszorozva egy megközelítő értéket kapunk. Egy tudományegyetem esetén 
(mint a közgazdasági egyetem) az üzleti képzésben egy egyetemi tanár értékelésénél a heti öt munkanap megosztása a következö: két nap oktatás, két nap kutatás, egy nap tanácsadás. Ha éves szinten kétezer munkaórával számolunk, és a bruttó bér ötmillió forint, akkor ebből a kutatásra fordított rész kétmillió forint. Ezután már „csak” azt kell megbecsülni, hogy a kutatási produktumból mennyi volt az exportnak számító tevékenység. Ez nagyon részletes és alapos elemzést igényel, legalább olyant, mint amit az oktatás területén megszoktunk.

Tételezzük fel, hogy a kutatási produktum csak két termékben nyilvánul meg: könyv és szakcikk. Mindkettő lehet magyarul (belföldi termék), illetve angolul (exporttermék). Ahhoz, hogy forintban kifejezhessük az egyes termékek értékét, előbb valamilyen mesterséges mértékegységben összemérhetővé kell tenni őket. Ilyen lehet egy pontrendszer. Tegyük fel, hogy egy professzornak 100 pontot kell a kutatási termékeiből összehozni az éves fizetésért. Ez azt jelenti, hogy minden egyes pont 8 munkaórát, vagy 20 ezer forintot jelent. Attól függően, hogy milyen portfóliót vár el a munkáltató a kutatótól, eltérő súlyokat ad az egyes tevékenységeknek. Ha a monográfiaírás a fontos, akkor egy ívnyi könyv vagy könyvfejezet több pontot ér, mint egy szakcikk. Ha pedig a külföldi publikáció (export), akkor egy angol nyelvü cikkért kétszer annyi pontot lehet kapni, mint egy magyar nyelvüért. Ha a minőség fontos, akkor egy A kategóriájú lapban megjelent cikkért kétszer annyi pontot lehet kapni, mint egy B kategóriájú lapban megjelentért. (Vagy egy impakt faktorú cikkért kétszer annyi pont jár, mint egy 0,5 impakt faktorúért.) Folytathatnánk tovább a rendszer finomítását. A lényeg, hogy viszonylag egyszerüen jutunk el ahhoz, hogy megbecsüljük a kutatási produktumok indirekt exportértékét.

\section{Tanármobilitás, vendégtanár, külföldi munkavállalás}

Az egyetemek nagy hangsúlyt helyeznek arra, hogy munkatársaik közreműködjenek külső szervezetek munkájában, akár pénzért, akár pénz nélkül. Az intézmény rangját (márkaértékét) emeli, ha a kormány, a média vagy a nagyvállalatok szakértőként az ő munkatársaikat kérik fel. Ugyanilyen módon érdeke füzödik az intézménynek ahhoz, hogy munkatársai külföldön kutassanak, oktassanak és egyéb szakértői tevékenységet végezzenek. Ekkor az ország mellett az intézmény nemzetközi hírnevét is emelik. Nem jellemző, hogy ennek az értékét a hazai viszonyok között számszerüsítenék az intézmények. Éppen ezért a szórványosabbnak tekinthető ilyen jellegű exporttevékenység számbavétele módszertanilag segíthet a belföldi tevékenység számbavételében is. (Csak zárójelben jegyezzük meg, hogy a több egyetemen is feladatot vállaló, ún. intercity-professzorság ennek egyik egyértelmü megnyilvánulása belföldön, amit sajnos egyes politikusok többnyire negatívan értékelnek Magyarországon.)

A tanárok egy része folyamatosan, egyedi szerződés vagy tartós alkalmazás alapján (mint vendég- vagy társult professzor) oktatást/kutatást végez külföldi egyetemeken. Ebben az esetben a kapott bér az alapja az exporttevékenység számításának. Ezt minden egyes munkatárs a konkrét megbízás alapján tudja kalkulálni. Legyen szó kutatásról, oktatásról, szakértésről vagy bármilyen egyéb tevékenységről, az export meghatározása kétféleképpen történhet. A legegyszerübb módszer, amikor a megbizó az ellenszolgáltatás teljes összegét átutalja egy magyar bankba a megbízott számlájára (például egy négyhetes oktatásért egy amerikai egyetem 5000 eurót fizet). Ekkor a tanárnak kell minden költséget fedeznie. A lakásbérlés (1000 euró) vagy a kinti egyéb kiadások (élelmiszer, közlekedés stb. körülbelül 
400 euró) csökkentik a nettó exportot. A repülőjegyet (600 euró) a Malévnál vagy egy külföldi légitársaságnál lehet megvásárolni. Ez módosítja az ország export-import mérlegét. Ha az utóbbi történik, akkor az 5000 euró bruttó exportbevételből végül 3000 euró kerülhet haza, mint nettó export.

A másik, gyakran alkalmazott forma, hogy a meghívó fél közvetlenül fedezi a költségek egy részét, például vendégprofesszori lakás biztosításával (a piacinál olcsóbb, 600 eurós költségen), teljes ellátással (olcsóbban, 300 euróért), a repülőjegy megküldésével (szintén olcsóbban, 500 euróért). Ebben az esetben a megbízó közvetlenül 3000 eurót utal át a magyar bankba a megbízott számlájára. A megbízott számára piaci áron 2000 eurós költség helyett azonban a vendéglátó egyetemnek csak 1400 euró költsége merül fel. Az ő szempontjukból 600 euró megtakarítás jelentkezik az importoldalon, hiszen nekik most 4400 euróba kerül a külföldi professzor egyhavi tanítása.

Ha egy professzornak egy évben két hónapja (a munkaidejének $20 \%$-a) van arra, hogy szakértőként bármilyen tevékenységet végezzen, akkor ez azt jelenti, hogy ilyen feltételek mellett maximálisan (azaz két teljes hónap külföldi oktatás esetén) 6000 euró, azaz közel 1,5 millió forint exportjövedelmet realizálhat. Ezzel éves szinten a jövedelme 30 százalékkal, 6,5 millió forintra növekedett. Ha 400 munkaórát számolunk a két hónapra, akkor ez a lehetőség 3750 forintos óradíjnak felel meg. Ha ezt összehasonlítjuk azzal, hogy mit lehet keresni idehaza ezzel a 400 órával, ha mondjuk vállalati tanácsadást vagy intercityprofesszorságot vállal valaki, akkor egyértelmüvé válik, hogy a kiváló oktatók számára miért nem motiváló tényező az export.

Az eddigiekben azt feltételeztük, hogy fóállású tanárokról van szó, akik csak munkaidejük engedélyezett részét (illetve annak kisebb hányadát) töltik exporttevékenységgel. Az intézménynek azonban - éppen a dolgozói szabad szellemi foglalkozású voltából kiindulva - érdeke füződne ahhoz, hogy fizetés nélküli szabadságot is adjon a külföldi munkavállaláshoz, szakértéshez. A globális piacon csak az jelentheti a versenyképességet, ha ezt az intézmény, valamint az egyén is bátran felvállalhatja. Az „intercountry” professzorság irányába való elmozdulás az egyénnek, az intézménynek és az országnak is érdeke. Ezt tekinthetnénk a rugalmas munkavállalás egyik közbenső állomásának, ami nem szükségszerüen vezetne el a teljes külföldi munkavállaláshoz.

\section{Oktatáshoz, kutatáshoz kapcsolódó egyéb szolgáltatások mint exporttevékenység}

Az élenjáró egyetemek a 20. században egy komplex szolgáltatást nyújtó intézménnyé, egyetemi várossá (angol kifejezéssel campus) váltak. Az alaptevékenységet jelentő oktatás, kutatás mellett számtalan egyéb szolgáltatást nyújtanak: kollégium, szállás, sport, egészségügy, kereskedelem, konferenciaszervezés stb. Az erre szakosodott szervezetekben egyre többen dolgoznak. Csak egy példa ennek illusztrálására: az Egyesült Államok legjobb tíz állami egyeteme közé tartozik a Washington Egyetem (Seattle), amelynek az éves árbevétele 2,2 milliárd dollár, azaz körülbelül 350 milliárd forint. Ekkora összeggel az egész magyar felsőoktatás rendelkezik. A 43 ezer diákot 3360 oktató és további 13280 dolgozó szolgálja ki. A tanár/dolgozó arány 20 \%, azaz minden tanárra négy másik alkalmazott jut (Sadlak-Cai 2007:44). Ez jelzi, hogy az oktatáson, kutatáson túl milyen sok egyéb tevékenység zajlik az egyetemi város falai között, amelyek egy része exporttevékenység. 
A külföldi hallgatók, tanárok, konferencia-résztvevők elszállásolása nagyvonalúan a turizmus kategóriába sorolható, amit elláthat az egyetem vagy más intézmény. A külföldi állampolgárok által látogatott sportlétesítmény, vendéglő stb. bevétele is exporttevékenység. Az egyetem vállalkozó jellegétől függ, hogy milyen mértékben él ezekkel a lehetőségekkel. A trendek azt mutatják, hogy a vezetö egyetemek (például Harvard, INSEAD bennlakásos vezetőképzési rövidprogramjai) költségvetésében ezek az exportjövedelmek egyre nagyobb hányadot tesznek ki.

\section{A tudásexport hierarchikus modellje}

Áttekintve a felsőoktatási tudásexport négy fő területét, a következő kérdés, hogy a statisztikai számbavétel milyen módon történjen, kire terjedjen ki. Ebből a szempontból rendező elvként célszerü a megfogható javak - mint például a gépkocsi - esetében alkalmazott módszereket is figyelembe venni. Természetes mértékegységben nézve pontosan tudja a szakma, hogy a világon évente mennyi autót gyártottak, milyen régióban, milyen gyárakban, milyen típusokból, és folytathatnánk a sort. Ha a piacot nézzük, akkor a nagy kereskedő vállalatok mellett az egyén is megjelenhet mint értékesítő (használtautó-piac) és mint vevő a nemzetközi piacon is. A szakma érdeke volt, hogy kitermelt egy viszonylag átlátható, transzparens piaci információs rendszert. Egy olyan rendszert, ahol az egyes szereplők érdeke, hogy az üzleti titoktartást nem feladva, megosszák egymással a tudásukat.

A felsőoktatási piacon ennek a folyamatnak a kezdetén vagyunk. A helyzetet nehezíti a szolgáltatási jellegü terméksajátosság, viszont elméletben könnyíti, hogy nagyrészt közpénzekből finanszírozott tevékenységről van szó, ahol a törvény nagyobb átláthatóságot követel meg (Svensson 2007). Másrészt a tudomány közjószág jellege miatt tulajdonképpen „publikus” a publikáció, azaz mindenki számára hozzáférhető, „csak” számba kell venni. Mindezeket figyelembe véve egy hierarchikus, alulról építkező modellt javasolunk a tudásexport számbavételére.

A tudásexport legelemibb szintje az egyén, az oktató, a kutató, a munkavállaló, aki egyénként és egy nagyobb szervezet tagjaként közremüködik az exportban. A legátfogóbb szint pedig a világ összes egyetemének produktuma. E két szint között a szervezeti egymásra épülés logikája alapján további nyolc szintet kell megkülönböztetni. Az ily módon képzett tíz szint abból a szempontból is érdekes, hogy a fejlődés és a verseny minden szinten értelmezhető. Van, ahol ez a verseny erősebb, van, ahol gyengébb, attól is függően, hogy a piacgazdaság játékszabályait milyen mértékben engedjük rá az egyes rendszerelemeknek. Mindenféle értékítélet nélkül a leíró jellegü tudományos megközelitést követve fogjuk a következőkben bemutatni az egyes szinteket.

A felsőoktatási tudásexport négy területének, illetve a következőkben tárgyalandó tíz hierarchikus szintnek a kombinációja egy $4 \times 10$-es mátrixhoz vezet (1. táblázat). A mátrix egyes celláinak naturális és pénzügyi adatokkal való kitöltése után juthatunk el az export nagyságának meghatározásához. A statisztikai számbavétel általában az egyetem (4. szint), az ország (6. szint) és a világ (10. szint) vonatkozásában rendelkezik többnyire naturális mutatókkal. Egy jól müködő teljesítménymutatókkal rendelkező egyetemen azonban az egyén (1. szint) vonatkozásában is lehetőség van az export meghatározására.

Ennek a holisztikus, az egész tevékenységi körre kiterjedő és minden hierarchikus szintet magában foglaló rendszernek az a fö előnye, hogy alkalmas a különböző vezetési szintek döntéshozóinak befolyásolására. Így például a dékán, a rektor vagy az oktatási 
miniszter az alárendelt szervezetek adatainak összehasonlítása alapján komplexen tudja megítélni az intézményt, egyértelmű ösztönzési rendszert tud kidolgozni a célok megvalósítása érdekében.

1. táblázat

A tudásexport horizontális és vertikális szintjei

\begin{tabular}{|l|l|l|l|l|l|}
\hline Hierarchikus szintek & $\begin{array}{c}\text { Diák- } \\
\text { mobilitás }\end{array}$ & $\begin{array}{c}\text { Tudományos } \\
\text { kutatás }\end{array}$ & $\begin{array}{c}\text { Tanár- } \\
\text { mobilitás }\end{array}$ & $\begin{array}{c}\text { Egyéb } \\
\text { szolgáltatás }\end{array}$ & $\begin{array}{c}\text { Összes } \\
\text { export }\end{array}$ \\
\hline 1. Oktatók, kutatók & & & & & \\
\hline $\begin{array}{l}\text { 2. Tanszékek, } \\
\text { intézmények }\end{array}$ & & & & & \\
\hline $\begin{array}{l}\text { 3. Karok, } \\
\text { tudományterületek }\end{array}$ & & & & & \\
\hline $\begin{array}{l}\text { 4. Egyetem, több } \\
\text { tudományterületet átfogó } \\
\text { oktatási központok }\end{array}$ & & & & & \\
\hline $\begin{array}{l}\text { 5. Azonos } \\
\text { tudományterület egy } \\
\text { országban }\end{array}$ & & & & & \\
\hline $\begin{array}{l}\text { 6. Egy ország összes } \\
\text { egyeteme }\end{array}$ & & & & & \\
\hline $\begin{array}{l}\text { 7. Egy régió azonos } \\
\text { tudományterületü } \\
\text { karainak exportja }\end{array}$ & & & & & \\
\hline $\begin{array}{l}\text { 8. Egy régió összes } \\
\text { egyetemének exportja }\end{array}$ & & & & & \\
\hline $\begin{array}{l}\text { 9. A világ azonos } \\
\text { tudományterületü } \\
\text { egyetemi karainak } \\
\text { exportja }\end{array}$ & & & & & \\
\hline $\begin{array}{l}\text { 10. A világ összes } \\
\text { egyetemének exportja }\end{array}$ & & & & & \\
\hline
\end{tabular}

Vannak olyan szintek, ahol magának a tevékenységnek a számbavétele sem megszokott, így még inkább nehézségbe ütközik az export bármilyen értelmezése. Máshol pontos mértékegységekkel rendelkezünk az export egyes elemeire vonatkozóan (mint publikáció vagy külföldi hallgató). Jóllehet a hierarchikus rendszer magasabb szintjei az alacsonyabb szintekre épülnek, éppen a számbavétel eltérő dimenziói miatt nincs mindig lehetőség az alacsonyabb szint mechanikus összegzésére ahhoz, hogy a magasabb szint teljesítményét megkapjuk. A következökben néhány területet részletesebben, míg másokat csak röviden elemezünk. 


\section{Oktatók, kutatók, adminisztratív személyzet mint az exporttevékenység alanyai}

Egy felsőoktatási intézmény minden dolgozójának fel lehet tenni a kérdést, hogy milyen mértékben vesz részt az exporttevékenységben. Van, aki a saját döntése alapján teszi, van, aki a munkája jellegéből adódóan és van, akinek a munkaköri leírásában is szerepel. A külföldi hallgatókkal foglalkozó iroda minden munkatársa exporttevékenységet folytat, akárcsak egy külföldi vendégekre szakosodott utazási iroda. Mások munkaidejük egy részét fordítják erre. Ebben az esetben a munkaidö-elemzés segít az exporttevékenység meghatározásában.

Korábban már bemutattuk, hogy egy akadémiai státusban lévő munkatárs szabad tanácsadási időkeretére milyen módon lehet elszámolni a külföldi oktatást. Ha rendelkezünk egy pontrendszerrel az oktatási, kutatási, oktatás- és kutatásszervezési feladatokra vonatkozóan, miként korábban feltételeztük, akkor minden egyes tételen végig kell menni és meghatározni, hogy a pontok milyen része származik exporttevékenységből. Ha a tanár 10 pontot kap azért, mert egy tárgyat egy idősávban tanít, akkor ez mind exportnak minősül, ha csak külföldi hallgatók ülnek a padokban. Ha van néhány külföldi hallgató, akkor az ő számukat el kell osztani az összlétszámmal, majd ezt meg kell szorozni a pontszámmal, és az így kapott pontszámot lehet exporttevékenységként jóváíni.

Természetesen az első alkalommal a nehezen besorolható eseteket értelmezni kell, és ki kell alakítani egy állásfoglalást. Így például, ha egy angol nyelvü, külföldön megjelenő újságban történő publikálásért 15 pont jár, akkor ez teljes egészben exportnak tekinthető, hiszen azt vélelmezzük, hogy az olvasók túlnyomó többsége külföldi. Ha azonban ez a lap Magyarországon jelenik meg, és csak korlátozott számban forgalmazzák külföldön, akkor itt ismét becslésre van szükség. A becslés alapja az lehet, hogy a nyomtatott példányok milyen aránya fogy el külföldi piacon. Ha 60 százaléka, akkor 0,6x15=9 pontot lehet jóváírni exportként.

Egy nemzetközi konferencia szervezéséért járó pontszámnál az előzőek szerint lehet eljárni, így például a külföldi résztvevők arányával lehet korrigálni a megadott, tételezzük fel, 10 pontszámot. Egy nagyszabású, a szakma éves nemzetközi találkozójának megszervezése azonban sokkal több időt igényel, mint a munkaidömérlegben ennek megfelelő 10x8=80 munkaóra. Ilyenkor a szabad szakmai időkeret vagy az „egyéni túlórakeret” áll rendelkezésre, mondjuk, egy további 100 munkaóra fedezetéül. A lényeg, hogy az egyén exportmérlegében - ha most már forintosítani is akarjuk a tevékenységet $-(80+100) \times 2500=450000$ forint jelenik meg, 200 ezer forint helyett.

\section{Tanszékek, intézmények, kutatócsoportok}

$\mathrm{Az}$ egyetemek belső szabályozásától függ, hogy milyen tevékenységek pénzügyi elszámolása történik meg tanszéki, intézeti, kutatócsoporti szinten, azaz az egyes alapvető szervezeti egységekben. Ahol erre nem kerül sor, ott értelemszerüen nem is gondolkodnak exportban. A mi logikánk alapján azonban a legegyszerübb módon úgy lehet becslést készíteni a tanszék (használjuk csak ezt a szervezeti megnevezést) exporttevékenységéröl, ha a tanszéket alkotó személyek intézményi pontrendszere alapján kalkulálható export tevékenységét összegezzük. Ha például három egyetemi tanár van, és ők a pontrendszerük szerint 15, 
45, 85 pontnyi exporttevékenységet realizáltak, akkor ennek alapján a tanszék exportbevétele $145 \times 20000=290$ ezer forint.

Az általunk javasolt rendszer alkalmas arra, hogy a különböző hierarchikus szinteken a döntéshozók (tanszékvezetők, dékánok, igazgatók, rektorok, miniszterek stb.) a céljaiknak megfelelö döntést hozzanak. A tanszékvezető a külső akkreditálásnál szembesül azzal, hogy ha a tanszékén öt év alatt öt magyar nyelvü könyv készült, de egyetlen olyan idegen nyelvü cikk sem, amely A, B kategóriás lapban jelent meg, akkor elkezd gondolkodni az okokon. Ha egy átlagos könyvre 50 pontot, azaz 50X20000=1000 000 forintot lehetett elszámolni, és a kiadótól a szerző még további 500 ezer forintot vett fel honoráriumként, akkor egy könyv megírása 1,5 millió forintot hozott a szerzőjének. Ha egy A, B kategóriás külföldi lapban megjelent cikk 15 pontot jelent, és szerzői honorárium nincs, akkor ez 300 ezer forintot hoz a szerzőjének. Teljesen világos, hogy egyéb motiváció hiányában a munkatársak könyvet fognak írni és nem szakcikket.

\section{Karok, tudományterületek}

A karok azok a szervezeti egységek, ahol az exporttevékenység már komplexen értelmezhető. Nevezetesen, mind a négy felsőoktatási tudásexport-piacon való jelenlét vizsgálható. Ha a kar adja a diplomát, a szakot, akkor minden rajta kérhető számon. Mivel karonként (gépészmérnök, közgazdasági, kertészeti, jogi, hogy néhányat említsünk) az alaptevékenység jellege is eltérö, ezért mások a normatívák, a tudásigények és így a nemzetköziség jelentősége is. A kar dönthet arról, hogy az export milyen területekre terjedjen ki, azaz oktatásban, kutatásban vagy egyéb szolgáltatásban kelljen élen járni. A kar számára célszerü elkészíteni egy mátrixot, ahol a függőleges tengelyen vannak továbbra is a tudásexport fö területei, míg a vízszintes oszlopokban a tanszékek, intézetek jelennek meg.

\section{Egyetem, több tudományterületet átfogó oktatási központok}

Az új magyar felsőoktatási törvény szándéka szerint a karok egyre merevebb határait is szerette volna oldani. Ezért a törvény szinte minden rendelkezése az egyetemre vonatkozik, ugyanakkor az egyetemi belső szabályozások szinte minden jogot a karokhoz delegáltak (Barakonyi 2004). A nemzetközi versenyképességben azonban nagy szerepe van az egyetemeknek mint komplex igazgatási egységeknek (Hrubos 2004). Olyan szervezeteknek, amelyek képesek kihasználni a méretgazdaságosságon túl az interdiszciplináris együttmüködésből származó előnyöket is.

Egyre inkább megfigyelhető trend, hogy a nagy ausztrál, amerikai, német egyetemek a nemzetközi szervezeteik élére diplomatákat, üzletembereket állítanak, akik képesek az üzleti, diplomáciai életben szerzett tapasztalataikat a felsőoktatási ágazatban is kamatoztatni. Egyetemi szintű erőforrás-koncentrációra van szükség ahhoz, hogy a nagy külföldi régiókat stratégiai szinten tudja megcélozni egy egyetem. Hiába látja mindenki, hogy az ázsiai piac a hallgatói mobilitás terén mennyire nő, csak az egyetemek képesek ezt tudatos politikával kiaknázni.

Ugyancsak egyetemi szintü összefogásra van szükség, hogy a nemzetközi kutatási programokból részesedjenek. Éppen a globális piac, illetve az Európai Felsőoktatási és 
Kutatási Térség létrejötte miatt az egyetemnél kisebb szervezeti egységek nem tudnak bekapcsolódni ezekbe a folyamatokba, hacsak a méreteik (árbevétel, létszám, épületek, stb.) ezt nem teszik lehetővé. Az elhíresült sanghaji rangsorba ezért többnyire többkarú, klasszikus nagy, történelmi egyetemek tudtak bekerülni. Három magyar egyetem is található a 201-500 közötti tartományban, míg Csehországból csak egy, Lengyelországból pedig ilyen egyetem volt (Sadlak - Cai 2007:358).

$\mathrm{Az}$ egyetemre is el lehet készíteni egy olyan tudásexport mátrixot, ahol a sorokban a karok szerepelnek. Az egyetemi szinten még inkább elképzelhető, hogy az exportot együttesen veszik számba. Ez történik a publikációknál, de a külföldi diákoknál is, amikor központi szervezetek foglalkoznak e témákkal. Ez jellemző az egyéb szolgáltatások területére, ahol az infrastrukturális beruházások, oktatási, sport-, konferencia-, kulturális, szálloda-, stb. létesítmények egyetemi kezelésben vannak, így azok külpiaci, exportcélra történő hasznosítása is egyetemi szinten mérhető. Erre akkor kerül sor, ha az egyetem valóban úgy viselkedik, mint egy gazdálkodó egység (Hrubos 2004).

\section{Azonos tudományterületü egyetemi karok egy országban}

A piaci igények, kulturális különbségek, történelmi hagyományok és még sok egyéb tényező játszik szerepet abban, hogy egy-egy országban milyen szakterületeken képeznek embereket. Így például hagyományosan Németországban vagy Japánban magasabb a mérnöki tudományokat szerzö hallgatók aránya, mint az Egyesült Államokban.

Az Egyesült Államok tíz legfontosabb tudományterülete a 2006/2007-es tanévben, ahol külföldi hallgatók tanultak: üzlet és menedzsment (18\% együtt), mérnöki terület (15\%), testnevelés és élettudományok (9\%), társadalomtudomány (8\%), matematika és számítástudomány (8\%), szépművészet és iparművészet (5\%), egészségügyi szakmák (5\%), intenzív angol nyelv (4\%), oktatás (3\%) és bölcsészettudomány (3\%) (IIR, Opendoors 2007).

Az egyetemek rangsorolása is többnyire karonként, szakonként történik. Magyarországon 170 kar versenyez egymással. Ebben a versenyben egyelöre elsősorban a hallgatókért folyik a harc: az állami fejkvóta alapján juttatott támogatási keretekért, a fejlesztési részhozzájárulásért, a tandíjért és az exportpiacokért. Míg az első három területen a magyar piac korlátozottsága miatt a verseny egymás rovására folyik, addig az utóbbi exportpiacokon a verseny win-win kimenetelü. Itt ha a magyar orvostudománynak jó híre van, akkor az pozitív hatással van az összes magyar egyetem exportpiaci eredményeire - éppen a magyar piac világpiachoz mért kis terjedelme miatt.

\section{Egy ország összes egyetemének exportja}

Egy ország összes egyeteme exporttevékenységének nagyságát legegyszerübben úgy kapjuk meg, ha a már említett módon összegezzük az egyes egyetemek exportforgalmát, azaz alulról építkezünk. Ehhez azonban szükség lenne azokra az adatokra, amelyekkel nem rendelkezünk. Ha majd rendelkezésre állnak, akkor el lehet készíteni az említett mátrixot, ahol a sorokban az egyes egyetemek szerepelnek. Az OECD például felmérést végez arról, hogy a tagországaiban milyen a munkaerő- és a diákáramlás. Ennek alapján lehet tudni, hogy mintegy nyolcezer magyar diák tanul vagy háromezer magyar dolgozik külföldön kutatóként. 
Bár a publikációk számbavétele alapján készült országrangsorok nem adnak teljes képet az exportról, de jó közelítő értékei a tudományos exportnak.

\section{Egy régió azonos tudományterületü egyetemi karainak, intézményeinek exportja}

A globális piacon régiók versenye zajlik. A régiók lehetnek országcsoportok - mint a visegrádi négyek -, vagy az EU-hoz újabban csatlakozó 12-ek, illetve a csatlakozás előtti 15 uniós tagország, Délkelet-Ázsia tíz országa, és folytathatnánk a sort. De lehetnek országhatárokon átívelő, egyes országok régióit magukban foglaló területek (mint a Kárpátalja régió: Magyarország, Szlovákia, Ukrajna, Románia, Lengyelország) is. Az ilyen típusú együttmüködések általában tudományterületekhez kapcsolódnak.

\section{Egy régió összes egyetemének exportja}

Számunkra az Európai Felsőoktatási Térség egyetemeinek exportja a legfontosabb. Annak ellenére, hogy tudjuk, a kelet-közép-európai régió nagyon lerontja ezeket a statisztikákat. A korábban említett alulról építkező, az egyes országok adatait összegző megközelítés ami a nemzeti statisztikai számbavételre épít - itt is csak korlátozottan alkalmazható. Kevés ország rendelkezik olyan alapos statisztikai rendszerrel, mint az Egyesült Államok.

Viszont a globalizáció következtében egyre több ilyen hatáskörű szervezet alakul. Ennek legnagyobb szervezete a diákmobilitásban az Egyesült Államok és egész ÉszakAmerika vonatkozásában a NAFSA, Európában a European Association of International Education (EAIE), míg Ázsiában az Asia Pacific Association of International Education (APAIE). Az általuk szervezett konferenciák, diákvásárok, kiállítások jó képet adnak a régiók exportképességéről.

\section{A világ azonos tudományterületü egyetemi karainak, intézményeinek exportja}

A Financial Times vagy más orgánumok által készített egyetemi világrangsorok, már ami az élmezőnyt illeti, jó lehetőséget adnak annak megítéléséhez, hogy például az orvostudomány vagy a mérnöki tudományok leginkább exportorientáltak. Az export egyes területei is nagy különbséget mutatnak. Míg a természettudományban szélesebb körünek látszik a publikációs export (lásd az impakt faktor szerepét), addig az üzleti tudományban a diákmobilitás exportösszetevője az erősebb. Ennek mértéke azonban más lehet a szegényebb és a gazdagabb országok esetében, vagy a fejlödés különböző szakaszaiban. Éppen ettől izgalmas e statisztikák elemzésre, előrejelzésre, illetve döntésre való felhasználása. A tudományos publikációk között eddig elsősorban a szakcikkeket említettük. Ezt sokan vitatják, mondván, a könyvek, monográfiák legalább ilyen fontos összetevői a tudományos eredménynek, exportnak. Ennek piaca kétségtelenül része az exportnak. 


\section{A világ összes egyetemének exportja}

A tudáspiac, ezen belül a felsőoktatási piac sok évszázadon keresztül globális volt, hiszen a latin nyelven tanult mindenki, és viszonylag kevés egyetem szolgált ki nagy területeket Európában is. Tehát a diákok többsége nem az anyaországában, anyanyelvén tanult, hanem külföldön. Bologna, Párizs, Bécs, Krakkó, Prága stb. egyetemein a hallgatóság többsége külföldi volt. A 19. században a nemzeti nyelv, majd a 20. században a felsőoktatás tömegszerűvé válása miatt a korábban exportorientált piac „belföldivé” vált. Mára a felsőoktatásban tanuló 120 millió hallgató közül csupán 2,5 millió a külföldi állampolgár. Ez az arány ebben az évszázadban drámaian meg fog változni - legalábbis a trendek és a felsőoktatás életgörbéje ezt jelzi.

Ugyanez vonatkozik a kutatási, valamint a felsőoktatáshoz kapcsolódó vendéglátási, szolgáltatási tevékenységekre, amelyek a GDP-ből növekvő arányt hasítanak ki. Egyre többen dolgoznak ebben a szektorban. 2025-re egyes becslések a hallgatók számát 250 millióra teszik, amelyen belül nyolcmillió lehet a külföldi. Az ezt kiszolgáló ipar, kereskedelem növekedése is vélelmezhető.

\section{Összefoglaló megállapítások}

Miként a bevezetőben megfogalmaztuk, egy gyakorlatban használható elméleti keretet kívántunk felvázolni annak illusztrálására, hogy a felsőoktatás mint iparág megjelenik az exportpiacokon. Jóllehet a felsőoktatás-export GDP-ben mért aránya még elenyésző, de stratégiai jelentősége miatt eljött az ideje annak, hogy elkezdjünk foglalkozni a méréssel. A vállalatgazdasági, közgazdasági és üzemgazdasági megközelítések (Polónyi 2002), (Varga 1998) mellett szükség van a nemzetközi kereskedelmi (Szentes 2005), nemzetközi marketing (Mazzarol - Normann 2001) és az erőforrás-alapú (Massey 1996) megközelítésekre is. Tanulmányunk ebbe az irányzatba sorolható. Zárógondolatként a felvázolt holisztikus modell továbbfejlesztése elméleti és a gyakorlati teendőire térünk ki.

A felsőoktatás finanszírozási rendszerének kialakításánál elsősorban annak van döntő szerepe, hogy a felsőoktatási termék mennyiben közjószág, illetve magánjószág. Az első esettel a hallgatók számára ingyenes felsőoktatás hívei érveltek és érvelnek, ahányszor a probléma felmerül. Azok, akik arra helyezik a hangsúlyt, hogy a hallgató a piacon jól értékesíthető diploma esetén magánjószághoz jut, joggal vetik fel, hogy ebből a haszonból előbb vagy utóbb a közösség is részesedjen. A tandíj, a költségtérítés, a diákhitel vagy az utólagos költségtérítés gondolata erre vezethető vissza. Ennek elemzése különösen izgalmas a nemzetközi diákmobilitás esetében.

A fejlett nyugat-európai országok megtehetik, hogy a saját polgáraikhoz hasonlóan ingyenesen vagy minimális költségtérités ellenében fogadnak külföldi hallgatókat. Ha azonban a külföldi hallgatók aránya meghalad egy bizonyos szintet (5-10\%), akkor már a gazdasági következmények sem elhanyagolhatók. Az európai angol nyelvü programok általában a fejletlenebb országokban tandíjasak, a skandináv államok ezt is ingyen, a nemzeti hallgatókéhoz hasonló feltételekkel nyújtják. Ebben az esetben vizsgálni kell a pozitív externáliákat, amelyek kompenzál(hat)ják a kieső tandíjakat.

A nemzetközi kereskedelem egyik magyarázó elmélete a komparatív elöny, amelynek értelmezése a felsőoktatási tudásexportra alapkutatásokat igényel. Miért éri meg egy gazdag 
országból származó hallgatónak egy szegény országban tanulni? Miért jön létre csere, illetve miért lehet exportképes egy szegény ország? Ennek megválaszolása a termék mellett az egész felsőoktatási piac működésének közgazdasági, menedzsment-, üzleti, marketing- és egyéb szempontok szerinti elemzését igényli.

A tudásexport egyetemi ágazatban történő kiszámítása számtalan elméleti, számbavételi és nyilvántartási nehézségbe ütközik. Ezt csak konkrét, gyakorlatias kutatások tudják megváltoztatni. Így például az Egyesült Államokban viszonylag jó az adatbázis a diákmobilitást illetően. Meg kell próbálni ezt a rendszert adaptálni más országokra is.

A publikációk, szakcikkek egyes köreire vonatkozóan az egyénekből kiindulva nagyon jó hierarchikus rendszert lehet felépíteni. A különböző intézményi rangsorok általában ezt teszik. Így például a Financial Times az MBA-rangsorok összeállításánál egyik szempontként azt vizsgálja, hogy az intézményből hány cikket publikáltak az általuk kiválasztott 40 vezető szaklapban a kutatók. Az intézmények Magyarországon is évente számolnak be a kutatási eredményekről (könyvek, könyvfejezetek, szakcikkek, konferencia-előadások stb. száma), de ezek nem válnak a vezetés meghatározó indikátoraivá. Sikeres helyzeteket bemutató esettanulmányok tudnák ezt kiegészíteni. Egy megbízható, következetesen mért exportteljesítmény-mutató mindenkinek jól jönne.

\section{Hivatkozások}

Barakonyi Károly (2004): Rendszerváltás a felsőoktatásban. Akadémiai Kiadó, Budapest, 350.

Belfield, C. R. - Levin, H. M. (2003): The Economics of Higher Education. An Elgar Reference Collection, Cheltenham.

Berács József (2003): Aszimmetriák és felzárkózási esélyek a felsőoktatási szolgáltatások nemzetközi kereskedelmében. Megjelent: Blahó András (szerk.): Elmaradottság - fejlödés - átalakulás. Tanulmányok Szentes Tamás akadémikus 70. születésnapja tiszteletére, BKÂE Világgazdasági Tanszék, 63-74.

Berács József (2007): Felsőoktatási reform és exportképesség. Népszabadság, július 27. A diploma melléklet különkiadása, 2 .

Hrubos Ildikó (2004) (szerk.): A gazdálkodó egyetem. Felsőoktatási Kutatóintézet, Új Mandátum, Budapest.

Kornai János (1999): A rendszerparadigma. Közgazdasági Szemle, 46. évf. 7-8. szám, 585-599.

Massey, W. F. (1996): Resource Allocation in Higher Education. The University of Michigan Press, Ann Arbor.

Mazzarol, T.-S. - Normann, G. (2001): The Global Market for Higher Education. Sustainable competitive strategies for the new millenium, Edward Elgar, Chettenham, U.K.

Opendoors (2007): Fast Facts, IIR (Institute of International Education).

Polónyi István (2002): Az oktatás gazdaságtana. Osiris Kiadó, Budapest.

Porter, M. (1990-1998): The competitive advantage of nations. Macmillan Business, New York.

Sadlak, J. - Cai, L. N. (2007) (szerk.): The World-Class University Ranking: Aiming Beyond Status. UNESCOCEPES, Shanghai Jiao Tong University, Cluj University Press.

Szentes Tamás és munkaközössége (2005): Fejlődés, versenyképesség, globalizáció, I-II. Akadémiai Kiadó.

Svensson, G. (2007): Legal Requirements for Transparency in Appointments and Promotions in Swedish higher Education Institutions. International Journal of Public Sector Management, Vol. 20, Issue 2, $118-133$.

Varga Júlia (1998): Oktatás-gazdaságtan. Közgazdasági Szemle Alapítvány. 